\title{
Strategi Aliran Kebatinan Purwa Ayu Mardi Utama Dalam Mempertahankan Eksistensinya Di Ponorogo, Jawa Timur
}

\author{
${ }^{1}$ Anjas Baik Putra, ${ }^{2}$ Yuangga Kurnia Yahya \\ 1,2 Universitas Darussalam Gontor Ponorogo \\ Jalan Raya Siman, Kabupaten Ponorogo, Jawa Timur \\ Email : yuangga4@unida.gontor.ac.id
}

\begin{abstract}
This study aims to determine the existence of Purwa Ayu Mardi Utama strategy in Kesugihan village, Ponorogo. Researchers used a sociological approach to find out facts in the field related to Purwa Ayu Mardi Utama's group strategies in maintaining their existence in Ponorogo District. The results of this study indicate that Purwa Ayu Mardi Utama is still developing and has the most followers in Ponorogo. Purwa Ayu Mardi Utama also has two strategies to maintain its existence in this modern era; both are by its non-coercive rituals and socialization to the surrounding community in the form of social services. Their habits are carried out by involving young people and youth associations in the villages. PAMU also play a role in teaching Javanese literacy and its preservation. This attitude, the Ponorogo community sympathize with this group.
\end{abstract}

Keywords: Group of believers; Purwa Ayu Mardi Utama; Ponorogo; Sociology of religion.

\begin{abstract}
Abstrak
Penelitian ini bertujuan untuk mengetahui strategi eksistensi Aliran Kebatinan Purwa Ayu Mardi Utama di desa Kesugihan, Ponorogo. Peneliti menggunakan pendekatan sosiologi untuk dapat mengetahui fakta di lapangan terkait strategi aliran kepercayaan Purwa Ayu Mardi Utama dalam mempertahankan eksistensi mereka di Kabupaten Ponorogo. Hasi penelitian ini menunjukkan bahwasanya Purwa Ayu Mardi Utama hingga saat ini masih berkembang dan memiliki penganut yang terbanyak di Kabupaten Ponorogo. Purwa Ayu Mardi Utama juga memiliki 2 strategi untuk menjaga eksistensinya di era modern ini yaitu dengan ritualnya yang tidak memaksa dan sosialisasi kepada masyarakat sekitar dalam bentuk bakti sosial. Ritualritual mereka dijalankan dengan melibatkan generasi muda dan perkumpulan pemuda di desa-desa. PAMU juga berjasa dalam pengajaran baca tulis bahasa Jawa dan pelestariannya. Sikap inilah yang membuat masyarakat Ponorogo menaruh simpati dengan aliran ini.
\end{abstract}

Kata Kunci: Aliran Kebatinan; Purwa Ayu Mardi Utama; Ponorogo; Sosiologi Agama. 


\section{Pendahuluan}

Aliran kebatinan atau yang dikenal juga dengan aliran kepercayaan terhadap Tuhan Yang Maha Esa merupakan satu sistem kepercayaan di Indonesia. Sistem spiritual ini eksis di Indonesia di samping keberadaan agama, aliran, sekte atau madzhab suatu agama tersebut, serta bukan pula termasuk kepercayaan adat. ${ }^{1}$ Banyak ahli yang berpendapat bahwa agamaagama ini merupakan agama lokal yang dianut sebelum agama-agama besar dari luar Indonesia hadir atau masa pra-Islam. ${ }^{2}$

Angin segar keberpihakan pemerintah kepada penganut kebatinan di Indonesia muncul pasca era Reformasi dengan terbitnya TAP MPR tentang Garis Besar Haluan Negara 1999-2004. Dalam ketetapan tersebut, disebutkan bahwa salah satu arah pembangunan bidang kebudayaan adalah pembinaan kebudayaan nasional bangsa Indonesia yang bersumber pada warisan leluhur, termasuk kepercayaan kepada Tuhan Yang Maha Esa dalam rangka memelihara kerukunan hidup bermasyarakat dan membangun peradaban bangsa $^{3}$. Hal ini menunjukkan bahwa penganut aliran kebatinan memiliki tempat di masyarakat Indonesia dan dilindungi oleh negara.

Pengikut aliran kebatinan di Indonesia tidak memiliki jumlah yang pasti. Direktorat Pembinaan Kepercayaan di Kemendikbud memperkirakan jumlah mereka sekitar 10-12 juta dari total penduduk Indonesia4. Salah satu faktor pendorongnya adalah karena adanya pernyataan kebebasan beragama yang tercantum dalam UUD 1945 Pasal 29. Di samping landasan konstitusional tersebut, aliran kepercayaan banyak dianut masyarakat karena alasan spiritual. Berbagai krisis yang timbul pada masa perjuangan kemerdekaan menuntut orang mencari pegangan hidup dalam bentuk aliran kepercayaan ini. Bahkan, seiring perkembangannya, tidak sedikit aliran kepercayaan yang menyatakan diri sebagai agama atau minta diakui sebagai agama. $^{5}$

1 Ridin Sofwan, Menguak Seluk Beluk Aliran Kebatinan (Kepercayaan Terhadap Tuhan Yang Maha Esa) (Semarang: CV. Aneka Ilmu, 1999) p,1.

2 J Hasse, Bernard Adeney Risakotta, and Zainal Abidin Bagir, "Diskriminasi Negara Terhadap Agama Di Indonesia, Studi Atas Persoalan Posisi Hukum Towani Tolotang Pasca Pengakuan Agama Resmi," Jurnal Kawistara 1, no. 2 (2011): 181, https://doi.org/10.22146/kawistara.3918.

3 Ahmad Choirul Rofiq, "Kebijakan Pemerintah Terkait Hak Sipil Penghayat Kepercayaan Dan Implikasinya Terhadap Perkembangan Penghayat Kepercayan Di Ponorogo," Kodifikasia 8, no. 1 (2014): 1-22; Aryono Aryono, "Pergulatan Aliran Kepercayaan Dalam Panggung Politik Indonesia, 1950an-2010an: Romo Semono Sastrodihardjo Dan Aliran Kapribaden," Jurnal Sejarah Citra Lekha 3, no. 1 (2018): 58-68, https://doi.org/10.14710/jscl.v3i1.17855.

4 Frendy Kurniawan, "Seberapa Banyak Jumlah Penghayat Kepercayaan Di Indonesia?," Tirto.Id, 14 November 2017, diakses melalui https://tirto.id/seberapa-banyakjumlah-penghayat-kepercayaan-di-indonesia-cz2y. pada Senin, 28 September 2020, 2:43 PM

${ }^{5}$ Sofwan, Menguak Seluk Beluk Aliran Kebatinan (Kepercayaan Terhadap Tuhan Yang Maha Esa); H.M Rasyidi, Islam Dan Kebatinan (Jakarta: Yayasan Islam Studi Club Indonesia, 1967). 
Keberadaan aliran kepercayaan dalam wujudnya sebagai organisasi atau paguyuban yang beraneka macam dengan jumlah yang tidak sedikit. Organisasi-organisasi tersebut pada umumnya muncul setelah proklamasi kemerdekaan meskipun sebagian di antaranya memang telah ada semenjak masa pendudukan kolonial di Indonesia. Menurut catatan Pengawas Aliran Kepercayaan Masyarakat (PAKEM) Departemen Agama, jumlah aliran kebatinan pada tahun 1950-an mencapai kurang lebih 400 aliran, baik yang digerakan oleh organisasi-organisasi maupun bersifat perorangan. Beberapa aliran tersebut antara lain; Jawa Dipa, Sapta Dharma, Sumarah, Pangestu, Sunda Wiwitan, dan kelompok penghayat kepercayaan terhadap Tuhan Yang Maha Esa. 6

Berdasarkan data Kemendikbud pada tahun 2017 ada 187 kelompok penghayat kepercayaan yang tersebar di berbagai provinsi Indonesia. Data tersebut menunjukkan 50 kelompok aliran di Jawa Timur, 53 kelompok aliran di Jawa Tengah, 7 kelompok aliran di Jawa Barat, dan 12 kelompok aliran di Sumatra Utara. Selain itu, masih terdapat beberapa kelompok aliran di provinsi yang lain. ${ }^{7}$

Di kabupaten Ponorogo Provinsi Jawa Timur, terdapat dua puluh dua Aliran Kepercayaan. Beberapa di antaranya adalah Purwa Ayu Mardi Utama, Perguruan Ilmu Sejati, Pangestu, Sumarah, Sapta Darma, Tirto Nirwolo, Paguyupan Sadar Penggalih dan beberapa aliran kepercayaan yang lain. ${ }^{8}$ Purwa Ayu Mardi Utama (PAMU) adalah salah satu aliran kepercayaan yang terdapat di Ponorogo dan berpusat di Desa Kesugihan, Kecamatan Pulung. Aliran ini berdiri pada 1913 atas prakarsa Ki Joyo Purnomo di Banyuwangi dan kemudian disebarkan oleh anaknya, Ki Permadi ke Ponorogo pada 1949. Penganut aliran ini pada 2019 mencapai 8000 orang yang terdiri dari pemeluk agama-agama besar di Indonesia seperti Islam, Katolik, Budha, dan Hindu ${ }^{9}$.

Penganut kepercayaan ini memiliki jumlah terbanyak di Ponorogo bila dibandingkan dengan aliran kepercayaan lainnya. Bahkan penganutnya mengalami pertambahan setiap tahunnya. Berikut adalah daftar 5 penghayat dengan penganut terbanyak di Ponorogo pada 201410:

\footnotetext{
${ }^{6}$ Sofwan, Menguak Seluk Beluk Aliran Kebatinan (Kepercayaan Terhadap Tuhan Yang Maha Esa), p.9.

7 Moh Nadlir, "Ada 187 Kelompok Penghayat Kepercayaan Yang Terdaftar Di Pemerintah," Kompas, melalui https://nasional.kompas.com/read/2017/11/09/12190141/ada-187-kelompok-penghayatkepercayaan-yang-terdaftar-di-pemerintah?page=all, November 2017 diakses pada 9/10/2019.

8 Dharmanto, Buku Program Dan AD/ART Kepengurusan MLKI DMD Kabupaten Ponorogo 2015-2020 (Ponorogo: Pemerintah Kabupaten Ponorogo, 2019).

${ }^{9}$ Hasil wawancara dengan Sumadi, ketua PAMU di Ponorogo, pada 4 Juli 2019.

10 Rofiq, "Kebijakan Pemerintah Terkait Hak Sipil Penghayat Kepercayaan Dan Implikasinya Terhadap Perkembangan Penghayat Kepercayan Di Ponorogo.”, 17-18.
} 
Tabel 1. Penghayat Dengan Penganut Terbanyak di Ponorogo

\begin{tabular}{|c|l|l|c|}
\hline No & \multicolumn{1}{|c|}{ Nama Penghayat } & \multicolumn{1}{c|}{ Pemimpin } & Jumlah \\
\hline 1 & Purwa Ayu Mardi Utama & Suradi, Kasimin & 11.300 \\
\hline 2 & Ilmu Sejati & Suyitno, Bikan & 6000 \\
\hline 3 & Aliran Kebatinan "Perjalanan” & Gondowiyono & 6400 \\
\hline 4 & Sapta Dharma & Isno Puro & 2300 \\
\hline 5 & Pelajar Kawruh Jiwo (PKJ) & Agus Thumun & 680 \\
\hline
\end{tabular}

Sumber : Data Himpunan Penghayat Kepercayaan (HPK) Ponorogo, dalam Ahmad Choirul Rofiq, "Kebijakan Pemerintah Terkait Hak Sipil Penghayat Kepercayaan Dan Implikasinya Terhadap Perkembangan Penghayat Kepercayan Di Ponorogo," Kodifikasia 8, no. 1 (2014): 1-22

Hal ini bertolak belakang dengan aliran kepercayaan yang lainnya yang mana eksistensinya berkurang di era modern ini. Meskipun telah diakui eksistensinya di kolom KTP oleh Mahkamah Konstitusi11, namun secara de facto, keberadaan mereka masih mendapatkan diskriminasi di mata pemerintah dan masyarakat. ${ }^{12}$ Hal inilah yang membuat aliran penghayat, termasuk PAMU untuk berjuang mempertahankan eksistensinya secara mandiri bila dibandingkan agama-agama resmi yang telah diakui oleh negara. ${ }^{13}$

Perkembangan PAMU di Ponorogo ditengarai karena aliran ini memiliki ajaran dan nilai-nilai kebudayaan yang dapat diterima dengan generasi muda sehingga dapat tetap eksis. Meskipun di Ponorogo terjadi berbagai perubahan sosial yang diiringi bertambahnya jumlah penduduk, aliran ini tetap memiliki banyak pengikutnya. Penelitian ini bertujuan untuk mengetahui strategi PAMU dalam melestarikan ajarannya dan menarik minat masyarakat untuk bergabung dengan menggunakan pendekatan sosiologi.

11 Kompas.com (2019, 26 Feb). “Ada Aliran Kepercayaan Penghayat dalam E-KTP, Kemendagri Bantah Pemerintah tak Lagi Akui Agama lain melalui https://nasional.kompas.com/read/2019/02/26/14255651/ada-aliran-kepercayaanpenghayat-dalam-e-ktp-kemendagri-bantah-

pemerintah\#: : text $=\% 22$ Penghayat $\% 20$ Kepercayaan $\% 20$ diakui $\% 20$ secara $\% 20$ sah, $26 \% 2 \mathrm{~F}$ 2\%2F2019). Diakses pada 11 Juli 2020.

12 Mohamad Imron Rosadi, "Eksistensi Dan Ajaran Kelompok Penghayat Kaweruh Jawa Dipa Di Tulungagung," Dinamika Penelitian: Media Komunikasi Penelitian Sosial Keagamaan 15, no. 1 (2015): 69.

${ }^{13}$ Hasse, Risakotta, and Bagir, "Diskriminasi Negara Terhadap Agama Di Indonesia, Studi Atas Persoalan Posisi Hukum Towani Tolotang Pasca Pengakuan Agama Resmi.", p. 181. 


\section{Metode}

Penelitian ini bertujuan untuk mengetahui strategi aliran kebatinan Purwa Ayu Mardi Utama dalam mempertahankan eksistensinya. Penelitian ini adalah penelitian kualitatif dengan metode pengumpulan data menggunakan observasi, wawancara, dan dokumentasi ${ }^{14}$. Observasi dilakukan pada Juli 2019 hingga Februari 2020 di Dusun Kebun Agung, Desa Kesugihan, Kecamatan Pulung, Ponorogo. Observasi yang dilakukan meliputi kegiatan rutin aliran PAMU berupa ritual-ritual keagamaan dan kegiatan masyarakat lainnya. Wawancara yang dilakukan kepada Bapak Sumadi, Ketua PAMU di Ponorogo, Bapak Agung, Sekretaris organisasi PAMU di Ponorogo, dan Ki Mangun Joyo, sesepuh PAMU di Ponorogo.

Adapun dokumentasi yang berupa sumber primer berasal dari buku Program dan AD/ART Kepengurusan MLKI DMD kabupaten Ponorogo, Ponorogo : 2015-2020 dan Anggaran Dhasaring Kaweruh Pranataning Prikunan Purwa Ayu Mardi Utama. Cetakan : VIII karya Djoyopoernomo, R.M. tahun 2009. Kedua buku tersebut merupakan pedoman dasar dalam kegiatan PAMU. Selain kedua buku tersebut, sumber-sumber sekunder lainnya berupa buku dan artikel di jurnal dan media massa yang membahas tentang PAMU dan aliran penghayat.

Dari data tersebut akan diklasifikasikan ke dalam dua kelompok, yaitu ritual keagamaan dan kegiatan sosial. Data tersebut kemudian dianalisis dan dideskripsikan dengan bahasa atau kata-kata.

\section{Pengertian dan Sejarah Purwa Ayu Mardi Utama}

Purwa Ayu Mardi Utama secara harfiah terdiri dari beberapa kata. Purwa berarti amiwiti, wiwitan (awal,asal), Ayu berarti keslametan (keselamatan), Mardi berarti kencengi pambudi (Budi yang Luhur), Utama berarti kang tanpa cacat (sempurna). Dari kata-kata tersebut, Purwa Ayu Mardi Utama dapat difenisikan sebagai "asal atau dasar-dasar kehidupan tentang keselamatan dalam menuju kehidupan yang berbudi luhur dan sempurna". ${ }^{15}$ Aliran kepercayaan ini mengajarkan tentang Pranataning atau aturan-aturan tentang kehidupan manusia, mengajarkan tentang keselamatan dalam kehidupan serta cara hidup yang sempurna dengan budi luhur serta menghormati sesama manusia seperti memperlakukan pada dirinya sendiri.

Manusia diciptakan dengan berbagai perbedaan. Hal ini yang mendasari PAMU untuk mengajarkan etika kehidupan yang dititikberatkan pada perilaku dalam kehidupan bermasyarakat maupun bernegara. Dalam

14 Emzir, Metodologi Penelitian Kualitatif Analisis Data (Jakarta: Rajawali Press, 2016), p.50; Djunaidi Ghoni, Metodologi Penelitian Kualitatif (Depok: Ar-Ruzz Media, 2013), p.199.

15 R.M. Djojopoernomo, Anggaran Dhasaring Kaweruh Pranataning Prikunan Purwa Ayu Mardi Utama, Cetakan VI (Ponorogo: Purwa Ayu Mardi Utama, 2009), p.6. 
istilahnya adalah lakon, ${ }^{16}$ yaitu perilaku. Budi luhur dan puncak akhirnya ialah mendapat hidup yang sempurna. Mereka berpendapat bahwasanya hidup yang sempurna tidak dilihat dari segi materi saja, akan tetapi lewat cara hidup. Jika hidup sehari-hari sempurna, maka hal itu menunjukkan bahwa seseorang sudah mengerti asal atau dasar cara budi luhur.

Purwa Ayu Mardi Utama bukanlah agama, bukan organisasi dan bukan pula politik, melainkan sebuah ilmu tentang pirukunan atau tentang ilmu kehidupan kemanusiaan. ${ }^{17}$ Tujuan PAMU sama dengan kebatinan yang lainnya yaitu mendekatkan diri kepada Sang Pencipta. Namun, aliran ini memiliki cara yang berbeda dari segi budaya, ajaran, ritual, dan lain sebagainya dibandingkan aliran kebatinan lainnya. ${ }^{18}$

PAMU termasuk bagian dari agama Jawa yang berpengaruh dalam masyarakat Jawa. Hamka menganggap bahwa agama Jawa bukanlah agama dalam pengertian agama Islam, agama Kristen dan agama yang lainnya. ${ }^{19}$ Agama Jawa merupakan suatu ajaran yang turun temurun bagi orang Jawa, lama sebelum agama Islam masuk ke Tanah Jawa. Dalam ungkapan lainnya, agama ini dianggap merupakan budaya warisan nenek moyang yang dapat diartikan sebagai warisan penghayat terhadap ajaran-ajaran agama yang telah mereka peluk sepanjang sejarahnya. ${ }^{20}$

Secara keseluruhan, PAMU ialah ajaran yang mengajarkan tentang budi luhur dan keselamatan dalam hidup untuk mencapai hidup yang sempurna. Dalam bahasa mereka adalah Kaweruh Pranataning Kamanungsan, ${ }^{21}$ ajaran yang mengajarkan tentang kemanusiaan. Ajaran ini membuat manusia mengetahui dari mana asalnya, apa yang harus dilakukan setelah hidup, dan kembali kepada Sang Maha Pencipta setelahnya. Ajara ini yang disebut pirukunan.

Purwa Ayu Mardi Utama didirikan oleh R.M Djodjopurnomo yang merupakan keturunan dari kraton Yogyakarta pada masa Kerajaan Mataram. R.M Djodjopurnomo membawa ajaran PAMU ke Jawa Timur yaitu di Banyuwangi dan mulai menyebarkan ajaran kemanusiaan kepada masyarakat. Ia mengajarkan tentang cara menanamkan rasa kesadaran diri yang menjadi utama, mengenal diri sendiri dan mempunyai kesadaran.

16 Hasil Wawancara Dengan Bapak Sumadi Ketua Lembaga PAMU, pada tanggal 0407-2019. Pada Pukul 14:00 WIB

17 Djojopoernomo, Anggaran Dhasaring Kaweruh Pranataning Prikunan Purwa Ayu Mardi Utama., p.6

18 Hasil Wawancara Dengan Bapak Sumadi Ketua Lembaga PAMU, pada tanggal 2102-2020. Pada Pukul 20:00 WIB

19 Hamka, Perkembangan Kebatinan Di Indonesia (Jakarta: Bulan Bintang, 1971), p.23.

20 Sofwan, Menguak Seluk Beluk Aliran Kebatinan (Kepercayaan Terhadap Tuhan Yang Maha Esa), p.14.

${ }^{21}$ Hasil Wawancara Dengan Bapak Sumadi Ketua Lembaga PAMU, pada tanggal 0407-2019. Pada Pukul 14:00 WIB 
Keasadaran ini ialah sesuatu yang dihadirkan sebagai basis dari kerukukan dan harmoni sosial. ${ }^{22}$

Secara resmi, aliran ini didirikan pada tahun 1912 di Banyuwangi di Desa Temuguruh Kecamatan Sempu Kabupaten Banyuwangi. Dalam perkembangannya, aliran ini memiliki banyak pengikut yang berasal dari berbagai kota, baik di Jawa Timur, Jawa Tengah, maupun di luar Pulau Jawa. Banyaknya penganut PAMU salah satunya disebabkan penyebarannya lewat keluarga dan anggota keluarga secara otomatis mengikuti kepercayaan orang tuanya. ${ }^{23}$

Salah satu cara menjaga eksistensi PAMU ialah adanya kaderisasi. Kaderisasi ini merupakan wewenang yang diberikan oleh sesepuh PAMU kepada orang tertentu untuk mendirikan pedepokan PAMU. R.M Djojopurnomo wafat pada tahun 1956 dan dikuburkan di Tojo yang sekarang menjadi pusat upacara peringatan wafatnya pada setiap tahunnya.

Sebelum wafat, R.M Djodyopurnomo memberikan amanah kepada wakil wirid, ${ }^{24}$ yaitu kepada Ki Marto Utomo yang ditugaskan untuk mendirikan pedepokan baru Purwa Ayu Mardi Utama di daerah Ponorogo, tepatnya di dusun Kebon Agung, desa Kesugihan, kecamatan Pulung, pada tahun 1949. ${ }^{25}$ Hal ini yang menjadi cikal bakal kelahiran PAMU di Ponorogo yang kemudian berkembang hingga saat ini.

Ki Marto Utomo meninggal pada tahun 1976. Setelah ia wafat, maka wakil wirid setelahnya dilanjutkan oleh Ki Surojo dan Ki Warsimin. Sejak tahun 2015, Ki Mangun Joyo diangkat sebagai Wakil Wirid PAMU yang merupakan amanah dari sesepuh PAMU pendahulunya ${ }^{26}$.

Aliran kebatinan ini memiliki perbedaan dengan aliran kebatinan lainnya di Ponorogo dalam hal pengikut. Dalam data di padepokan PAMU, pengikut mereka mencapai 8000 jiwa. Dalam kurun waktu 2011-2019, terdapat 501 orang yang masuk ke dalam keanggotaan PAMU dengan jumlah detail sebagai berikut ${ }^{27}$ :

${ }^{22}$ Hasil Wawancara Dengan Bapak Sumadi Ketua Lembaga PAMU, pada tanggal 0407-2019. Pada Pukul 14:00 WIB

${ }^{23}$ Hasil Wawancara Dengan Bapak Sumadi Ketua Lembaga PAMU, pada tanggal 0407-2019. Pada Pukul 14:00 WIB

${ }^{24}$ Hasil Wawancara Dengan Ki Mangun Joyo Sesepuh PAMU, pada tanggal 21-022020. Pada Pukul 20:30 WIB

${ }^{25}$ Hasil Wawancara Dengan Bapak Sumadi Ketua Lembaga PAMU, pada tanggal 0407-2019. Pada Pukul 14:00 WIB

26 Hasil Wawancara Dengan Ki Mangun Joyo Sesepuh PAMU, pada tanggal 21-022020. Pada Pukul 20:30 WIB

${ }^{27}$ Pengurus PAMU, Buku Induk Keanggotaan Purwa Ayu Mardi Utama, n.d. 
Tabel 2. Keanggotaan PAMU

\begin{tabular}{|c|c|c|}
\hline No & Tahun & Jumlah Anggota Baru \\
\hline 1 & 2011 & 22 orang \\
\hline 2 & 2012 & 52 orang \\
\hline 3 & 2013 & 29 orang \\
\hline 4 & 2014 & 39 orang \\
\hline 5 & 2015 & 35 orang \\
\hline 6 & 2016 & 71 orang \\
\hline 7 & 2017 & 98 orang \\
\hline 8 & 2018 & 68 orang \\
\hline 9 & 2019 & 87 orang \\
\hline \multicolumn{2}{|c|}{ Total Keseluruhan } & $\mathbf{5 0 1}$ orang \\
\hline
\end{tabular}

Sumber : Buku Induk Keanggotaan PAMU

\section{Strategi Purwa Ayu Mardi Utama Dalam Mempertahankan Eksistensi}

Sebagaimana disebutkan di atas, PAMU memiliki beberapa strategi dalam menjaga eksistensinya di era modern ini. Strategi mereka terbagi ke dalam dua hal, yaitu pelestarian ajaran mereka dan kegiatan kemasyarakatan. Kedua hal ini yang menjadi magnet penarik generasi muda untuk ikut bergabung ke dalam aliran ini dan membuat masyarakat Ponorogo bersimpati pada aliran ini.

\section{Ritual-ritual Purwa Ayu Mardi Utama}

Beberapa ritual PAMU yang rutin dilaksanakan adalah Perwitan, Suran, Sarasehan, Rabunan Pon, Jum'at Kliwon, Minggu Kliwon, malam Jum'at, dan Ruah. Pelaksanaan ritual-ritual ini beragam, sesuai dengan waktu masingmasing. Ada yang bersifat insidental seperti ritual Perwitan dan ada pula yang dilakukan sesuai waktu-waktu yang ditentukan yaitu hari-hari berdasarkan kalender Jawa seperti Suran di bulan Sura, Ruah di bulan Ruah, Rabu Pon, Jum'at Kliwon, dan Minggu Kliwon.

Pertama adalah Ritual Perwitan. Ritual Perwitan adalah upacara penerimaan anggota baru bagi mereka yang pertama kali mempelajari PAMU. ${ }^{28}$ Istilah yang digunakan dalam PAMU ialah nunggal kaweruh. Upacara ini dilakukan sebagai pemberkatan bagi orang yang pertama kali masuk PAMU karena dianggap sebagai orang yang mendapatkan wahyu.

Kedua adalah Ritual Suran. Ritual Suran dilakukan pada malam tanggal 3 bulan Suro (bulan Muharram). Ritual ini dilakukan dalam bentuk slametan. Slametan tersebut dimaksudkan untuk kesalamatan diri sendiri atau orang-yang terdekat. Slametan adalah ritual yang dilaksanakan untuk

${ }^{28}$ Hasil Wawancara Dengan Bapak Sumadi Ketua Lembaga PAMU, pada tanggal 2102-2020. Pada Pukul 14:00 WIB 
peristiwa penting dalam kehidupan seseorang. Peristiwa penting tersebut seperti lahiran, kematian, pembangunan gedung, sunatan, panen raya, bahkan pernikahan.

Dalam slametan juga ada hidangan yang khas dan berbeda-beda seperti dupa, pembacaan do'a, dan pidato sesepuh dengan menggunakan bahasa Jawa tinggi yang sopan (kromo inggil). Meskipun acara slametan terkadang dilaksanakan secara ringkas, tetapi tetap menjadi acara yang penting untuk dilaksanakan. ${ }^{29}$

Ritual suran ini disebut juga dengan ritual sedekah bumi, ${ }^{30}$ yaitu memberikan sesajian seperti tumpeng, golong dan hasil panen apa adanya. Ritual ini guna mensyukuri atas nikmat hasil bumi yang telah diberikan kepada manusia. Dalam ritual ini, mereka menggunakan blangkon dan pakaian adat Jawa berwana hitam dengan jarik batik coklat yang terselip keris di belakangnya. Dalam pelaksanaannya, mereka memanjatkan doa' dan pujian dengan bahasa Jawa. Secara terpisah, mereka juga menambakan bacaan surah Yasin yang dibaca secara individu.

Ketiga adalah ritual Sarasehan. Ritual Sarasehan ini biasanya dilakukan oleh penganut anggota PAMU di Desa Kesugihan secara rutin. Ritual ini biasanya dilakukan di pedepokan PAMU atau di rumah anggota PAMU yang disepakati secara bergilir. Peserta ritual ini hanya sekitar 70-an orang saja dan mengundang d pihak kepala desa atau kecamatan bahkan dari pihak pemerintah untuk mengisi sambutan. Ritual ini adalah dalam rangka menjalin hubungan kelembagaan PAMU dengan masyarakat dan pemerintah. ${ }^{31}$

Keempat, Rabunan Pon. Ritual ini dilakukan ketika rabu pon 35 hari sekali. Ritual ini dilakukan secara kelembagaan atau organisasi PAMU tersendiri dilaksankan di pedepokan PAMU di pimpin oleh ketua Lembaga PAMU dan Sesepuh PAMU. Didalamnya membahas perkembangan organisasi PAMU, sosialisasi terhadap masyarakat, pembangunan dan membahas kegiatan-kegiatan PAMU yang dilaksanakan kedepannya. Ritual ini yang mengikuti hanya sekitar 70 an orang saja, Perkumpulan ini tidak semua anggota PAMU ikut serta, hanya utusan-utusan dari setiap kelompok saja. ${ }^{32}$

Ritual Kelima adalah ritual setiap Jumat Kliwon. Ritual Jumat Kliwon ini dilaksanakan pada tiap Jumat Kliwon atau satu kali dalam 35 hari. Ritual ini khususnya untuk memperingati wafatnya pendiri aliran ini yaitu Ki R.M. Djojopoernomo. Dalam pelaksanaannya, mereka melakukan doa bersama

${ }^{29}$ Clifford Geertz, Agama Jawa; Abangan, Santri, Priyayi Dalam Kebudayaan Jawa, Terj. Aswa (Depok: Komunitas Bambu, 2014), p.23.

30 Hasil Wawancara Dengan Bapak Agung Sekretsris Lembaga PAMU, pada tanggal 28-10-2019. Pada Pukul 14:00 WIB

${ }^{31}$ Hasil Wawancara Dengan Bapak Agung Sekretsris Lembaga PAMU, pada tanggal 28-10-2019. Pada Pukul 14:00 WIB

${ }^{32}$ Hasil Wawancara Dengan Bapak Agung Sekretsris Lembaga PAMU, pada tanggal 28-10-2019. Pada Pukul 14:00 WIB 
yang dipimpin oleh sesepuh PAMU yang bertempat di pedepokan PAMU. Setelah membaca doa bersama, acara dilanjutkan dengan sosialisasi hasil perkumpulan yang dilaksanakan pada Rabunan Pon sebelumnya kepada seluruh anggota.

Keenam adalah ritual Minggu Kliwon. Ritual Minggu Kliwon ini dilaksanakan pada setiap Minggu Kliwon. Ritual ini khususnya dilaksanakan untuk memperingati wafatnya pendiri aliran Purwa Ayu Mardi Utama di Ponorogo yaitu Ki Marto Utomo Purnomo. Sebagaimana ritual Jum'at Kliwon, ritual ini diisi dengan melakukan doa bersama yang dipimpin oleh sesepuh PAMU. 33

Ketujuh adalah ritual rutin setiap malam jumat. Dalam ritual ini, mereka mendalami dan memahami ajaran-ajaran PAMU yang diajarkan oleh sesepuh PAMU. Ritual ini dilaksanakan di padepokan mereka. Selain itu, mereka juga mereka mengembangkan budaya Jawa seperti belajar membaca dan menulis dengan menggunakan bahasa Jawa yang baik dan benar. Hal ini menjadi penting karena budaya Jawa tidak lagi mendapatkan perhatian bagi generasi muda di era modern. Dalam ritual Suran, mereka juga rutin mengadakan wayangan kulit sebagai usaha dalam melestarikan budaya Jawa.

Terakhir adalah Ritual Ruwah (Ruwatan). Ritual ini dilakukan setiap tanggal 15 bulan Ruwah (bulan Sya'ban). Kegiatan dalam ritual ini adalah melakukan berdoa bersama anggota PAMU kepada Tuhan Yang Maha Esa. Do'a ini merupakan wujud syukur atas nikmat yang telah diberikan kepada mereka dan mengirimkan doa kepada para leluhur. Ritual ini merupakan bentuk rasa hormat terhadap leluhur yang telah menuntun manusia. Dalam ritual ini, mereka juga mengadakan penampilan budaya wayangan kulit dan krawitan (gamelan Jawa). ${ }^{34}$

Berbagai ritual di atas secara tidak langsung juga melibatkan peran masyarakat sekitar. Dengan konsep kegiatan yang bersifat umum dan menghibur, mereka mampu menarik minat masyarakat untuk turut serta. Acara Suran dan Ruwah misalnya, diramaikan dengan wayang kulit dan krawitan yang merupakan hiburan kegemaran masyarakat.

\section{Kegiatan Sosial Purwa Ayu Mardi Utama}

Ajaran Kaweruh Kamanungsang ialah ajaran tentang pengetahuan kemanusiaan. Ajaran tentang bagaimana manusia seharusnya bersikap terhadap sesama manusia. Salah satunya ialah interaksi sosial terhadap masyarakat. Para pengikut PAMU dalam kehidupan sehari-harinya selalu berkecimpung dalam lapisan masyarakat. Acara apapun yang dilakukan masyarakat mereka ikut serta dalam mengikuti kegiatan tersebut. Mulai dari gotong royong, bersih desa, hingga pembangunan masjid seluruhnya diikuti

${ }^{33}$ Hasil Wawancara Dengan Bapak Sumadi Ketua Lembaga PAMU, pada tanggal 2602-2020. Pada Pukul 20:00 WIB

${ }^{34}$ Hasil Wawancara Dengan Bapak Sumadi Ketua Lembaga PAMU, pada tanggal 2602-2020. Pada Pukul 20:00 WIB 
oleh mereka. Tidak ada alasan yang membuat mereka untuk dijauhi atau diasingkan.

Adapun sosialisasi Aliran Kebatinan Purwa Ayu Mardi Utama terhadap masyarakat melalui beberapa kegiatan. Pertama, adalah kegiatan sosial pembangunan. Aliran kebatinan Purwa Ayu Mardi Utama di Ponorogo memiliki program sosial pembangunan untuk masyarakat dalam bentuk bantuan fasilitas yang dibutuhkan masyarakat di beberapa desa. Beberapa kegiatan yang mereka lakukan adalah pembangunan SDN Desa Kesugihan, Gedung Puskesmas Desa, Gedung Balai Desa dan bangunan-bangunan lainnya.

Kedua adalah kegiatan Bakti Sosial. Aliran Kebatinan Purwa Ayu Mardi Utama di Desa Kesugihan memiliki rasa sosial yang tinggi terhadap masyarakat. Beberapa kegiatan bakti sosial yang diadakan oleh Aliran Kebatinan Purwa Ayu Mardi Utama diantaranya mengadakan kegiatan Satitah $^{35}$, yaitu dari kelembagaan Aliran kebatinan Purwa Ayu Mardi Utama yang bertujuan mengumpulkan dana atau bantuan yang lainnya dengan seikhlasnya dan diberikan kepada masyarakat yang membutuhkan. Kemudian anggota PAMU juga ikut serta dalam kegiatan masyarakat seperti gotong royong, penghijauan desa, dan berbagai aktivitas warga yang lainnya. Berikut adalah beberapa fasilitas masyarakat yang dibangun secara gotong royong antara penganut PAMU dan masyarakat sekitar sebagaimana tertera di padepokan mereka hingga 2019:

Tabel 3. Fasilitas Masyarakat yang dibantu pembangunannya oleh Paguyuban PAMU

\begin{tabular}{|l|l|l|}
\hline No & \multicolumn{1}{|c|}{ Nama Fasilitas } & \multicolumn{1}{c|}{ Tempat } \\
\hline 1 & Penghijauan Jalan PUK & Kebon Agung \\
\hline 2 & Kantor Polisi Ngrayun & Kecamatan Ngrayun \\
\hline 3 & Gedung Puskesmas & Desa Kesugihan \\
\hline 4 & Jembatan (6 x 3,5 meter ) & Desa Bekiring \\
\hline 5 & SDN Kesugihan & Desa Kesugihan \\
\hline 6 & Gedung Balai Desa & Desa Kesugihan \\
\hline 7 & Saluran Aliran Air Irigasi & Desa Kesugihan \\
\hline 8 & Jembatan (Dheker) & Desa Kesugihan \\
\hline 9 & SD Wagir Lor (6 ruang ) & Kecamatan Ngebel \\
\hline 10 & Kamar Mandi Umum (4 buah) & Desa Wagir \\
\hline
\end{tabular}

Sumber : Hasil Observasi lapangan

35 Hasil Wawancara Dengan Bapak Sumadi Ketua Lembaga PAMU, pada tanggal 2602-2020. Pada Pukul 20:00 WIB 
Ketiga adalah kegiatan sosial kebudayaan. Dari segi kebudayaan, anggota PAMU ikut serta mengikuti beberapa agenda sosial kebudayaan seperti slametan desa, tumpengan, larungan atau sedekah bumi setiap bulan Muharram yang mereka laksanakan di Telaga Ngebel, Ponorogo. PAMU juga mempertahankan kebudayaan musik gamelan dan mempunyai alat tersendiri. Mereka mengajarkannya kepada warga desa yang berminat untuk belajar gamelan. Tak lupa pula, PAMU mengadakan kegiatan belajar membaca dan menulis bahasa Jawa dengan baik dan benar.

PAMU juga ikut berkesinambung dalam melestarikan kebudayaan Desa Kesugihan. Salah satunya adalah diadakan budaya bersih desa yang rutin yang dilaksanakan setiap tahunnya setiap tanggal 1 Muharram. Ini merupakan bentuk sosial antar sesama masyarakat desa Kesugihan. Kemudian PAMU juga mengadakan acara wayang kulit yang ditampilkan ke masyarakat setiap tanggal 15 bulan Ruah atau tanggal 15 sya'ban. ${ }^{36}$

Berdasarkan paparan pembahasan diatas, aliran kebatinan Purwa Ayu Mardi Utama mempunyai strategi tersendiri untuk tetap menjaga eksistensinya di era modern ini. Strategi tersebut adalah dengan tetap menjalankan berbagai ritual-ritual PAMU, baik yang dilaksanakan bersama masyarakat maupun ritual hanya khusus untuk anggota PAMU saja. Aliran Kebatinan Purwa Ayu Mardi Utama juga memiliki sosialisasi terhadap masyarakat. yaitu berkecimpung dalam lapisan masyarakat dan melestarikan budaya masyarakat setempat. Pendekatan ini merupakan salah satu pendekatan dalam menciptakan ruang perjumpaan dalam rangka menarik simpati masyarakat. ${ }^{37}$

Aliran kebatinan Purwa Ayu Mardi Utama memiliki peran andil terhadap masyarakat yaitu memberikan bantuan dan fasilitas terhadap masyarakat maupun desa, seperti membangun lembaga pendidikan, lembaga kesehatan desa, pagar jalan dan berbagai fasilitas yang lainnya. Hal ini yang mendukung aliran dapat diterima di berbagai kalangan masyarakat dan tetap eksis di era modern ini. Karenanya, tidak mengherankan apabila aliran ini menjadi salah satu aliran kebatinan yang memiliki pengikut terbanyak di daerah Ponorogo.

${ }^{36}$ Hasil Wawancara Dengan Bapak Sumadi Ketua Lembaga PAMU, pada tanggal 2602-2020. Pada Pukul 20:00 WIB

37 Yuangga Kurnia Yahya, "Toleransi Antar Agama Dan Antar Etnis Di Desa Mamahak Teboq Kalimantan Timur," Palita: Journal of Social-Religion Research 3, no. 2 (2018): 178, https://doi.org/10.24256/pal.v3i2.56. 


\section{Kesimpulan`}

Purwa Ayu Mardi Utama (PAMU) memiliki strategi untuk tetap menjaga eksistensi nya. Adapun faktor-faktor yang memperkuat keberadaan PAMU adalah tidak adanya paksaan seseorang untuk menganut PAMU, mengajarkan tentang kemanusiaan, kerukunan dan peraturan-peraturan dalam kehidupan yang dijalani oleh manusia.

Dalam menjaga eksistensinya, PAMU tetap menjalankan ritual-ritualnya secara rutin dan melibatkan masyarakat secara luas. Selain itu, PAMU juga berkecimpung dalam kehidupan sosial kemasyarakatan baik dari segi sosial pembangunan, bakti sosial dan juga menjaga kebudayaan Jawa di masyarakat. Hal ini yang membuat aliran ini dapat diterima di kalangan masyarakat dan tetap eksis dengan penganut yang banyak di saat aliran kebatinan lainnya mengalami penurunan pengikut.

\section{Daftar Pustaka}

Aryono, Aryono. "Pergulatan Aliran Kepercayaan Dalam Panggung Politik Indonesia, 1950an-2010an: Romo Semono Sastrodihardjo Dan Aliran Kapribaden." Jurnal Sejarah Citra Lekha 3, no. 1 (2018): 58-68. https://doi.org/10.14710/jscl.v3i1.17855.

Dharmanto. Buku Program Dan AD/ART Kepengurusan MLKI DMD Kabupaten Ponorogo 2015-2020. Ponorogo: Pemerintah Kabupaten Ponorogo, 2019.

Djojopoernomo, R.M. Anggaran Dhasaring Kaweruh Pranataning Prikunan Purwa Ayu Mardi Utama. Cetakan VI. Ponorogo: Purwa Ayu Mardi Utama, 2009.

Emzir. Metodologi Penelitian Kualitatif Analisis Data. Jakarta: Rajawali Press, 2016.

Geertz, Clifford. Agama Jawa; Abangan, Santri, Priyayi Dalam Kebudayaan Jawa. Terj. Aswa. Depok: Komunitas Bambu, 2014.

Ghoni, Djunaidi. Metodologi Penelitian Kualitatif. Depok: Ar-Ruzz Media, 2013.

Hamka. Perkembangan Kebatinan Di Indonesia. Jakarta: Bulan Bintang, 1971.

Hasse, J, Bernard Adeney Risakotta, and Zainal Abidin Bagir. "Diskriminasi Negara Terhadap Agama Di Indonesia, Studi Atas Persoalan Posisi Hukum Towani Tolotang Pasca Pengakuan Agama Resmi." Jurnal Kawistara 1, no. 2 (2011): $180-90$. https://doi.org/10.22146/kawistara.3918.

Kurniawan, Frendy. "Seberapa Banyak Jumlah Penghayat Kepercayaan Di Indonesia?" Tirto.Id, n.d. https://tirto.id/seberapa-banyak-jumlahpenghayat-kepercayaan-di-indonesia-cz2y.

Nadlir, Moh. "Ada 187 Kelompok Penghayat Kepercayaan Yang Terdaftar Di Pemerintah." Https://Nasional.Kompas.Com, 2017.

Pengurus PAMU. Buku Induk Keanggotaan Purwa Ayu Mardi Utama, n.d.

Rasyidi, H.M. Islam Dan Kebatinan. Jakarta: Yayasan Islam Studi Club Indonesia, 1967. 
Rofiq, Ahmad Choirul. "Kebijakan Pemerintah Terkait Hak Sipil Penghayat Kepercayaan Dan Implikasinya Terhadap Perkembangan Penghayat Kepercayan Di Ponorogo." Kodifikasia 8, no. 1 (2014): 1-22.

Rosadi, Mohamad Imron. "Eksistensi Dan Ajaran Kelompok Penghayat Kaweruh Jawa Dipa Di Tulungagung." Dinamika Penelitian: Media Komunikasi Penelitian Sosial Keagamaan 15, no. 1 (2015): 67-80.

Sofwan, Ridin. Menguak Seluk Beluk Aliran Kebatinan (Kepercayaan Terhadap Tuhan Yang Maha Esa). Semarang: CV. Aneka Ilmu, 1999.

Yahya, Yuangga Kurnia. "Toleransi Antar Agama Dan Antar Etnis Di Desa Mamahak Teboq Kalimantan Timur." Palita: Journal of Social-Religion Research 3, no. 2 (2018): 165-80. https://doi.org/10.24256/pal.v3i2.56. 